\title{
Does Pegylated-Interferon Still Have High Efficacy Treatment Properties Against Chronic Hepatitis B?
}

\section{Pegile-Interferon Kronik Hepatit B'de Hala Yüksek Etkili Tedavi Özelliklerine Sahip mi?}

\author{
๑ Figen SARIGÜL YILDIRIM1, ๑ Ülkü USER1, ๑ Murat SAYAN2,3, ๑ Nefise ÖZTOPRAK1 \\ 1 University of Health Sciences, Antalya Training and Research Hospital, Clinic of Infectious Disease and Clinical Microbiology, Antalya, Turkey \\ 2Kocaeli University Faculty of Medicine, Clinical Laboratory, PCR Unit, Kocaeli, Turkey \\ ${ }^{3}$ Near East University, Research Center of Experiment Health Sciences, Nicosia, Northern Cyprus
}

\section{ABSTRACT}

Objectives: Pegylated-interferon (Peg-IFN) alpha $2 \mathrm{a} / 2 \mathrm{~b}$ and nucleoside and/or nucleotide analogues (NAs) are currently the only two treatment approaches approved for the chronic hepatitis B (CHB). To date, few studies have compared Peg-IFN with NAs in the treatment of CHB. We aimed in this study to evaluate the effectiveness of Peg-IFN and potent NAs (entecavir and tenofovir disoproxil) and to compare cumulative virological and serological responses in Turkish CHB patients treated between 2006 and 2016. Materials and Methods: In this observational retrospective study, we divided a total of 331 patients, who were diagnosed with $\mathrm{CHB}$, into 3 groups: Peg-IFN treatment group ( $n=62)$, entecavir treatment group ( $n=131)$ and tenofovir disoproxil treatment group $(n=138)$.

Results: Virologic response rate in the Peg-IFN treatment group $(90 \%)$ at 12 months was higher than in the NAs treatment groups (80\% for entecavir and $76 \%$ for tenofovir disoproxil) $(p<0.05)$. Sustained virologic response (SVR) rate at 24 months was $61 \%$ in the Peg-IFN group $(p<0.001)$. The rate of hepatitis $B$ e antigen seroconversion was significantly higher in the Peg-IFN group (25\%) than in the NAs groups $(16 \%$ for entecavir, $13 \%$ for tenofovir disoproxil). Hepatitis B surface antigen (HBsAg) seroconversion rate was also higher in the Peg-IFN than in the NAs treatment groups $(7.9 \%$ vs. $0.9 \%$ and $0 \%$, respectively) $(p<0.001)$. After HBsAg seroconversion, the titers of anti-HBs were retained for over six months.

Conclusion: Peg-IFN treatment was found to be effective with high SVR and hepatitis $B$ e antigen and HBsAg seroconversion rates than NAs treatment in long-term follow-up of patients with CHB. Peg-IFN appears to be the first-choice treatment approach in patients with CHB until a new era in which hepatitis $B$ is cured.

Keywords: Chronic hepatitis B, pegylated-interferon, nucleoside/ nucleotide analogues, hepatitis B surface antigen, seroconversion
\end{abstract}

$0 ̈ Z$

Amaç: Pegile-interferon (Peg-IFN) alfa $2 \mathrm{a} / 2 \mathrm{~b}$ ve nükleozid ve nükleotid analogları (NA), şu anda kronik hepatit B (KHB) tedavisi için onaylanmış iki tedavi yaklaşımıdır. Bugüne kadar birkaç çalışma Peg-IFN ve NA'lar arasındaki tedavinin etkinliğini karşılaştırmıştır. Bu çalışmada, 2006-2016 yılları arasında Türk KHB hastalarında Peg-IFN ve potent NA'ların (entekavir ve tenofovir disoproksil) kümülatif virolojik ve serolojik yanıtlarını karşılaştırarak etkinliklerini değerlendirmeyi amaçladık.

Gereç ve Yöntemler: Retrospektif gözlemsel olan bu çalışmada KHB tanilı total 331 hasta (Peg-IFN tedavi grubu, $n=62$, entekavir tedavi grubu, $n=131$ ve tenofovir disoproksil tedavi grubu, $n=138$ ) değerlendirildi.

Bulgular: Virolojik yanıt oranı Peg-IFN tedavi grubunda 12. ayda (\%90), NA tedavi grubundan (entekavir için \%80, tenofovir disoproksil için \%76) daha yüksekti $(p<0,05)$. Peg-IFN'nin 24. ayda kalıc viral yanıt (KVY) oranı \%61 idi $(p<0,001)$. Hepatit $B$ e antijen serokonversiyonu Peg-IFN grubunda (\%25) NA grubuna (entekavir için \%16, tenofovir disoproksil için \%13) göre belirgin yüksekti. Hepatitis B yüzey antijeni (HBsAg) serokonversion oranı Peg-IFN grubunda NA tedavi grubuna göre daha yüksekti $(\% 7,9$ vs $\% 0,9$ ve \%0) $(p<0,001)$. HBsAg serokonversiyonundan sonra anti-HBs titreleri altı aydan fazla korundu.

Sonuç: KHB hastalarının uzun sureli takibinde Peg-IFNtedavisi, NA'larına göre daha yüksek KVY ile daha yüksek HBsAg ve HBeAg serokonversiyon ile ilişkili bulundu. Peg-IFN hepatit B virüsün tedavi edildiği yeni bir döneme kadar KHB hastalarında ilk seçenek tedavi yaklaşımı olarak görünmektedir.

Anahtar Kelimeler: Kronik hepatit B, pegile-interferon, nükleozid/ nükleotid analog, hepatit $B$ yüzey antijen, serokonversiyon

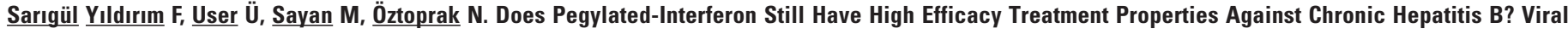
Hepat J. 2018;24:90-95. 


\section{Introduction}

Antiviral therapy is administered to prevent the progression of liver damage to cirrhosis, hepatocelluler carcinoma $(\mathrm{HCC})$ and death in patients with chronic hepatitis B (CHB). Currently, the available treatments for patients with $\mathrm{CHB}$ include pegylated-interferon (Peg-IFN) alpha 2a/2b and nucleoside/nucleotide analogues (NAs) $(1,2)$. Peg-IFN is an immunomodulator with antiviral activity against hepatitis B virus (HBV) (3). NAs (i.e., lamivudine, telbivudine, entecavir, adefovir, tenofovir disoproxil and tenofovir alafenamide) inhibit reverse transcriptase activity of HBV polymerase (pol) (4). A therapy leading to hepatitis surface antigen (HBsAg) seroconversion would avoid requirement of additional treatments. The difficulty in eliminating HBV is due to the persistence of covalently closed circular DNA (cccDNA) that integrates into the host DNA (5).

Most guidelines recommend entecavir or tenofovir (disoproxil/ alafenamide) and Peg-IFN, as monotherapy for the management of $\mathrm{CHB}(1,2,3,6)$. Deciding on the type of treatment depends on the patient's clinical status, HBV DNA load and the level of alanine aminotransferase (ALT) enzyme, hepatitis B e antigen ( $\mathrm{HBeAg}$ ) status, and liver histology $(1,2,3)$. Entecavir is preferred in older patients due to the low risk for nephrotoxicity and acceleration of bone loss. Tenofovir disoproxil is very effective against NAsresistant and wild type HBV strains $(7,8)$. Entecavir and tenofovir disoproxil, having similar high potency and genetic barriers, are used much more than Peg-IFN even in CHB patients with no contraindications to IFN (9). However, Peg-IFN is preferable in some circumstances, particularly in young patients eligible for shortened treatment duration. Peg-IFN has the advantages of absence of drug resistance, providing immune-mediated control of the HBV infection, the possibility of achieving a sustained virologic response (SVR), and the possibility of HBsAg loss in patients with an HBV DNA load of $<2000 \mathrm{IU} / \mathrm{mL}$. An additional advantage of Peg-IFN treatment is clearly established treatment duration of 48 weeks. On the contrary, the duration of NA therapy is yet to be clearly outlined $(1,2,3)$.

A systematic review of 339 studies on the prevalence of $\mathrm{CHB}$ in Turkey revealed that the prevalence of HBsAg was $4.5 \%$ in the Turkish population. This rate may increase to $9.8 \%$ in the eastern part of Turkey $(10,11)$. In our country, it is estimated that one out of every three people over 18 years of age has encountered HBV, in addition, more than 2 million adults have been reported to be $\mathrm{HBsAg-positive} \mathrm{(12).} \mathrm{The} \mathrm{rate} \mathrm{of} \mathrm{drug} \mathrm{spending} \mathrm{for} \mathrm{CHB}$ patients is $0.7 \%$ of the total and unfortunately, the rate for on treatment $\mathrm{CHB}$ patients is only $13.5-15 \%$ in Turkey (13). According to the data of the Intercontinental Market Services (IMS Health) in 2016, 61544 $\mathrm{CHB}$ patients in Turkey were receiving entecavir and tenofovir disoproxil treatment. The number of Peg-IFN-treated CHB patients has been reported to be 947 in 2016 in Turkey (14).

In this study, we aimed to evaluate the effectiveness of Peg-IFN and potent NAs. However, we compared cumulative virologic and serological responses in $\mathrm{CHB}$ patients over a given period of time.

\section{Materials and Methods}

\section{Patients}

In this retrospective observational study, we included 334 CHB patients treated with Peg-IFN ( $n=63)$, entecavir $(n=131)$ and tenofovir disoproxil $(n=140)$ between 2006 and 2016 in the department of infectious disease at University of Health Sciences Antalya Training and Research Hospital.

According to the European Association for the Study of the Liver guideline, the diagnosis of $\mathrm{CHB}$ was made based on histological, virologic, serological and biochemical data (2). Grade and stage of the CHB were assessed using the Ishak (14) modified histological activity index (HAl) (15).

Patients with co-infection with HIV and other viral hepatitis viruses, immunodeficiency disorders, decompensated cirrhosis, HCC or any other malignancies, injecting and other drug users, solid organ recipients, those non-compliant with treatment and patients who received treatment less than 12 months, or less than 3 months due to adverse effect or intolerance, pregnant women, and any patient under the age of 18 years were excluded.

All the patients were followed up by hepatitis B serology, biochemistry, and virology at 1, 3 and 6 months. HBV DNA and serology parameters were recorded at 3-month intervals after 12 months of therapy with Peg-IFN and NAs.

During NAs treatment, their HBV DNA, evaluated using polymerase chain reaction (PCR), was negative, showing virologic response. The duration of Peg-IFN treatment was 48 weeks for all patients. Virologic response has been defined as a HBV DNA value of $<2000 \mathrm{IU} / \mathrm{mL}$ (2). Both treatment groups were were evaluated for virologic response at 6 months and at the end of the treatment. $\mathrm{HBeAg}$ seroconversion was defined as loss of $\mathrm{HBeAg}$ and development of anti-HBe on at least two consecutive follow-ups. $\mathrm{HBsAg}$ seroconversion was defined as absence of serum HBsAg and presence of anti-HBs after a 6-month period.

Compliance to therapy was accepted if patients took their pills once daily at the same time (0.5 or $1 \mathrm{mg}$ entecavir and $245 \mathrm{mg}$ tenofovir disoproxil per day) and were injected Peg-IFN $(180 \mathrm{mcg}$ for $2 \mathrm{a}, 1.5 \mathrm{mcg} / \mathrm{kg}$ for $2 \mathrm{~b}$ ) weekly and regularly, without interruption (except for their physician advices). After the treatment started, any symptom or abnormal laboratory and clinical findings were accepted as drug-related adverse effect.

\section{Laboratory Analysis}

Serological markers of HBV were quantified by using chemiluminescence assay (Cobas platform, Roche Diagnostics, Mannheim, Germany), which has been the preferred test in the hospital since 1998. HBV DNA levels were quantified by sensitive real-time PCR (Abbott TagMan 2000, Illinois-Des Plaines USA) (lower limit as quantification, $10 \mathrm{JU} / \mathrm{mL}$ ) and has been in use in the hospital since 2008.

Antiviral resistance analysis was made in Kocaeli University by the Sanger dideoxy sequencing method as follows; oligonucleotides (forward primer: 5' - TCG TGG TGG ACT TCT CTC AAT T - 3' / reverse primer: 5'- CGT TGA CAG ACT TTC CAA TCA AT - 3') were used for the HBV pol gene amplification. There are the PCR reactions: $95{ }^{\circ} \mathrm{C}-10 \mathrm{~min}$. for 35 cycles and then $95{ }^{\circ} \mathrm{C}-45 \mathrm{~s}, 60$ ${ }^{\circ} \mathrm{C}-45 \mathrm{~s}$, finally $72{ }^{\circ} \mathrm{C}-45 \mathrm{~s}$. The primers concentration was 0.3 $\mathrm{mM}$. The amplicon size was $740 \mathrm{bp}$. A drug resistance tool that was Genafor/arevir (http://coreceptor.bioinf.mpi-inf.mpg.de/) used on the interpretation of $\mathrm{HBV}$ resistance mutations.

\section{Statistical Analysis}

One-Way ANOVA was conducted to compare the continuous variables such as baseline demographic and laboratory characteristics (age, baseline HBV DNA load, HAl, patient follow-up 
time, baseline ALT, fibrosis) between the subjects of Peg-IFN group and those of entecavir and tenofovir disoproxil group. Categorical variables (gender, $\mathrm{HBeAg}$ positivity, treatment status, and original type of therapeutic molecule) were compared using a chi-square test. The two-tailed t-test was conducted to compare the means of the HBV DNA monitoring between HBeAg-positive entecavir and tenofovir disoproxil treatment groups, Peg-IFN and $\mathrm{HBeAg-negative}$ entecavir patients as well as Peg-IFN and HBeAg-negative tenofovir disoproxil patients. Seroconversion rates were analysed using a chi-square test. A p value of $\leq 0.05$ was considered statistically significant. SPSS v13 programme was used for statistical analyses.

\section{Results}

There was no statistically significant difference in baseline age $(p=0.5)$, gender $(p=0.5)$, pretreatment mean ALT $(p=0.5)$, pretreatment HBV DNA ( $p=0.05)$, and duration of follow-up $(p=0.6)$ between the groups. NAs were also similar in terms of being original and generic drugs $(p=0.5)$. Baseline demographic and clinical and laboratory characteristics of patients are shown in Table 1. Basal liver biopsy was done in all patients in Peg-IFN and in NAs treatment group. The fibrosis score was significantly lower in the Peg-IFN treatment group $(p=0.001)$.

Peg-IFN was injected in 63 patients (one patient was excluded due to signs of depression), entecavir was given to 131 patients, and tenofovir disoproxil was given to 140 patients, two of whom were receiving combination treatment with tenofovir disoproxil and entecavir as high HBV DNA levels were keeping on with entecavir monotherapy without any resistance and incompliance. These two patients were excluded from evaluation. Only two patients had entecavir resistance, in these patients the mutations were identified at the gene loci rtL180M, rtM204V and rtS202G. The treatment was therefore changed to tenofovir disoproxil.
Subsequently, in these two patients, renal toxicity developed because of tenofovir disoproxil treatment, in turn the patients were instead treated with entecavir.

Amongst the Peg-IFN group, there were only four HBeAgpositive patients; evaluation of virologic response was not conducted for this group. Amongst HBeAg-negative patients, the the difference in the rate of HBV DNA suppression between the Peg-IFN and NAs groups were statistically significant for each month $(p<0.001$ at $3,6,24,36$ and 48 months, $p<0.05$ at 1 month and 12 month). Until 12 months of treatment, HBV DNA suppression was higher in the Peg-IFN group. By the second year of treatment (24 month), in the NAs group, the rates of HBV DNA suppression became higher $(p<0.001)$. In our study, the rate of virologic response was $90 \%$ at the end of the therapy and the SVR rate was $61 \%$ at 24 months amongst the Peg-IFN-treated patients. No statistically significant differences was found in HBV DNA suppression in NAs group between $\mathrm{HBeAg}$-positive and negative patients ( $p>0.1$ ). In NAs, the suppression of HBV DNA was above $90 \%$ after 48 months of treatment. HBV DNA suppression rates are presented in Table 2.

The rates of $\mathrm{HBeAg}$ seroconversion was $25 \%, 16 \%$ and $13 \%$ in the Peg-IFN, entecavir and tenofovir disoproxil treatment groups, respectively. The difference between the treatment groups was statistically significant $(p<0.001)$. No statistically significant difference was found in $\mathrm{HBeAg}$ seroconversion rate between the two NAs $(p>0.1)$. HBsAg seroconversion rates were $7.9 \%$ and $0.9 \%$ in the Peg-IFN and entecavir treatment groups $(p<0.001)$. However, HBsAg seroconversion was detected in the tenofovir disoproxil treatment group. $\mathrm{HBeAg}$ and $\mathrm{HBsAg}$ seroconversion rates are presented in Table 3.

Some patients had anti-HBs titers after HBsAg seroconversion. HBsAg seroconversion was accepted based on the disappearance

Table 1. Baseline demographic and laboratory characteristics of the study patients

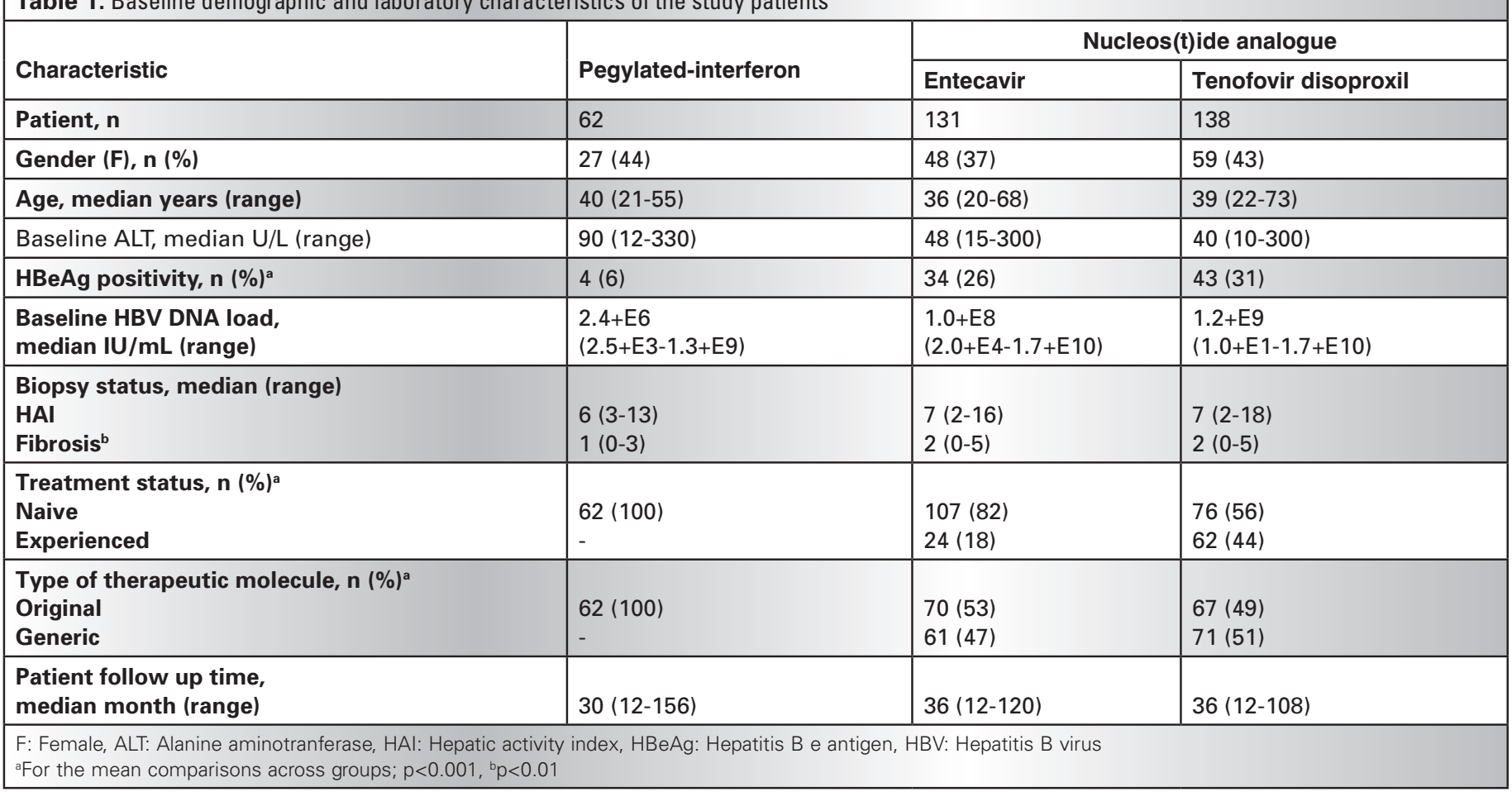


of serum HBsAg and the presence of anti-HBs for more than 6 months. Anti-HBs titers occurred in five patients in the Peg-IFN treatment group and in one patient in the NAs treatment group. Anti-HBs occurred only in the entecavir treatment arm. However, in the second tests, there was an increase in anti-HBs antibodies and continued for a further six months. The period of anti-HBs occurrence and anti-HBs titers detected are presented in Table 4.

\section{Discussion}

In the present study, the purpose was to compare the effectiveness of Peg-IFN and potent NAs treatments in $\mathrm{CHB}$ patients over an extended period (10 years). We used the standard parameters in both the serological and virologic responses. The rate of virologic response in the Peg-IFN group (90\%) at 12 months was higher than in the NAs treatment group $180 \%$ for entecavir and $76 \%$ for tenofovir disoproxil). In addition, in our study, the SVR at 24 months was higher $(61 \%)$ in the Peg-IFN group than in other studies. Information available regarding the treatment efficacy of Peg-IFN and NAs groups is limited. There is only one study from Turkey which compared the difference between Peg-IFN and adefovir treatment amongst a small CHB patient group (16). The rates for the virologic response at 48 weeks were similar to our study $190 \%$ for Peg-IFN, $80 \%$ for entecavir and 76\% for tenofovir disoproxil). In a multicenter cohort study from Korea, after the end of Peg-IFN treatment, virologic response rate in HBeAg-negative patients was $30 \%$ in a period of one year (17). However, Yamazhan et al. (18) reported that the response rate of Peg-IFN treatment was low at the end of treatment whereas one-year SVR in HBeAgnegative cases was $33 \%$. In the current study, patients in all treatment groups displayed similar outcome in terms of baseline parameters; the fibrosis score however was significantly lower in patients treated with Peg-IFN. The lower SVR responses in other studies may depend on patients selected for Peg-IFN treatment.

High virologic and SVR rates may lead to long-term viral suppression that is known to reduce the degree of liver damage and the risk of end-stage liver disease $(19,20)$. In the present study, HBV DNA suppression as a result of NAs treatment occurred in over $90 \%$ of cases after 48 months. It was long duration but long-lasting if the compliance to treatment provided perfect results could have been in the CHB patients treated with potent NAs. In a retrospective multicenter study conducted in Turkey, virologic response in patients treated with entecavir or tenofovir disoproxil therapy over a period of 4 years was similar to that in our NAs treatment group (21). On the other hand, there is a relationship between the concentration of HBV DNA and cirrhosis and HCC in patients with $\mathrm{CHB}$ (19). In our patients, who were on long-term follow-up, there were no HCC and cirrhosis in the two groups because Peg-IFN produced a high sustained off-treatment response, NAs evoked a high virologic response during uninterrupted therapy. Long-term NAs therapy has several disadvantages such as side effects, non compliance to therapy, reactivation and the risk of emergence of drug resistance by mutations (22). Although, the updated guidelines recommend discontinuation of NAs therapy (evidence level II-2, grade of recommendation 2) (23), patients

Table 2. Comparison of hepatitis B virus DNA supression in the pegylated-interferon and nucleos(t)ide analogue treatments in the study patient groups

\begin{tabular}{|c|c|c|c|c|c|}
\hline \multirow{3}{*}{$\begin{array}{c}\text { HBV DNA } \\
\text { monitorization, } \\
\text { (month) }\end{array}$} & \multicolumn{5}{|c|}{ HBV DNA supression } \\
\hline & \multirow{2}{*}{$\begin{array}{l}\text { Pegylated-interferona, } \\
\text { n (\%) }\end{array}$} & \multicolumn{4}{|c|}{ Nucleos(t)ide analogueb, $n(\%)$} \\
\hline & & \multicolumn{2}{|c|}{ Entecavir } & \multicolumn{2}{|c|}{ Tenofovir disoproxil } \\
\hline 1 & $22(35)$ & $2(6)$ & $19(20)$ & $2(5)$ & $18(19)$ \\
\hline 3 & $52(84)$ & $4(12)$ & $35(36)$ & $5(12)$ & $38(40)$ \\
\hline 12 & $56(90)$ & $10(29)$ & 77 (78) & $15(35)$ & $72(76)$ \\
\hline 18 & $50(80)$ & NA & - & NA & - \\
\hline $24^{\&}$ & $38(61)$ & $17(50)$ & $82(85)$ & $24(56)$ & $85(90)$ \\
\hline 36 & $41(66)$ & $22(65)$ & $88(92)$ & $37(86)$ & $90(96)$ \\
\hline 48 & $27(44)$ & $33(97)$ & $96(100)$ & $42(98)$ & $92(98)$ \\
\hline
\end{tabular}

Table 3. Hepatitis B e antigen and hepatitis B surface antigen seroconversion rate of the study patients

\begin{tabular}{|l|l|l|l|}
\hline \multirow{2}{*}{ Seroconversion status } & \multicolumn{3}{|c|}{ Chronic hepatitis B treatment } \\
\cline { 2 - 4 } & Pegylated-interferon & Entecavir & Tenofovir disoproxil \\
\hline Before tratment HBeAg positive, $\mathrm{n}(\%)^{\mathrm{a}}$ & $4(6)$ & $34(26)$ & $43(31)$ \\
\hline HBeAg seroconversion, $\mathrm{n}(\%)^{\mathrm{a}, \mathrm{b}}$ & $1(25)$ & $6(16)$ & $5(13)$ \\
\hline HBsAg seroconversion, $\mathrm{n}(\%)^{\mathrm{a}, \mathrm{b}}$ & $5(7.9)$ & $1(0.9)$ & $\mathrm{ND}$ \\
\hline $\begin{array}{l}\text { a For the mean comparisons across groups (pegylated-interferon and NAs) } \mathrm{p}<0.001, \mathrm{~b} \text { For the mean comparisons across groups (entecavir and tenofovir disoproxil) p>0.1, } \\
\text { HBeAg: Hepatitis B e antigen, HBsAg: Hepatitis B surface antigen }\end{array}$
\end{tabular}




\begin{tabular}{|c|c|c|c|c|c|}
\hline \multirow{2}{*}{ Therapy } & \multirow{2}{*}{ Patient } & \multirow{2}{*}{$\begin{array}{l}\text { Time of seroconversion, } \\
\text { years }\end{array}$} & \multicolumn{3}{|c|}{ Anti-HBs titer, IU/mL } \\
\hline & & & First testing ${ }^{\mathrm{a}}$ & $\begin{array}{l}\text { Second testing } \\
\text { (6 } 6^{\text {th }} \text { months) }\end{array}$ & $\begin{array}{l}\text { Duration of titer } \\
\text { ( }>6^{\text {th }} \text { months) }\end{array}$ \\
\hline \multirow{5}{*}{$\begin{array}{l}\text { Pegylated- } \\
\text { interferon }\end{array}$} & 1. & $5^{\text {th }}$ & 30 & 50 & 200 \\
\hline & 2. & $4^{\text {th }}$ & 20 & 400 & 400 \\
\hline & 3. & $4^{\text {th }}$ & 50 & 60 & 500 \\
\hline & 4. & $6^{\text {th }}$ & 50 & 500 & 400 \\
\hline & 5. & $5^{\text {th }}$ & 20 & 40 & 350 \\
\hline Entecavir & 1. & $5^{\text {th }}$ & 80 & 90 & 100 \\
\hline Tenofovir & ND & ND & ND & ND & ND \\
\hline
\end{tabular}

in whom the therapy is discontinued, must be closely followed for reactivation $(2,3,24)$. In low-income countries, the high cost of therapy limits the number of patients who receive treatment, which can ultimately influence the emergence of viral resistance on/off-treatment NAs in CHB patients (24).

As serological responses; HBeAg seroconversion rate was found to be significantly higher in the Peg-IFN group (25\%) than in the NAs group (16\% for entecavir and 13\% for tenofovir disoproxil). Despite the long-term follow-up, $\mathrm{HBeAg}$ seroconversion rates were lower in the NAs group. This finding was also demonstrated by Xing et al. (24) that in long-term treatment with potent NAs, $\mathrm{HBeAg}$ seroconversion with the therapy was lower compared with spontaneous HBeAg seroconversion rate (25). The latest study conducted by Marcellin et al. (26) in 2017 showed remarkable results of Peg-IFN treatment in long-term follow-up of $\mathrm{CHB}$ patients (26). In HBeAg-positive patients, HBeAg seroconversion increased from $23 \%$ at the end of treatment to $38 \%$ after 3 years of therapy. ENUMERATE which is the largest "real-world" entecavir treatment study showed that five-year HBeAg seroconversion was $33.7 \%$ (27). A study with tenofovir disoproxil treatment also demonstrated a $\mathrm{HBeAg}$ seroconversion rate of $40 \%$ (28). In our real-world data, Peg-IFN showed durable e seroconversion but in the NAs treatment group, there was some seroreversion, and an additional $16 \%$ and $13 \%$ of the patients would achieve $\mathrm{HBeAg}$ seroconversion in $\mathrm{HBeAg}$-positive $\mathrm{CHB}$ patients in the long-time period. Because of the immunomodulating effect of Peg-IFN that was sustained for a long time even after the end of therapy, no anti-HBe seroconversion in the Peg-IFN group was detected in the current study over the 10 years period.

In studies by Marcellin et al. (26), Ahn et al. (27), and Petersen et al.(28), HBsAg seroconversion rate was also clearly higher in Peg-IFN groups than in the NAs treatment groups $(7.9 \%, 0.9 \%$ and $0 \%$, respectively). The rate of HBsAg clearance 3 years after treatment was $2 \%$ in $\mathrm{HBeAg}$-positive patients and $5 \%$ in $\mathrm{HBeAg}$ negative patients treated with Peg-IFN; the rate of HBsAg loss was $4.6 \%$ for entecavir and the rate of $\mathrm{HBsAg}$ seroconversion was $0.8 \%$ for tenofovir disoproxil during long-term therapy $(26,27,28)$. The production of HBsAg is associated with HBV replication and the amount of intrahepatic cccDNA. Higher HBsAg seroconversion rate in the long-term Peg-IFN treatment may be due to their good immunomodulating, weak antiviral activity and potential of immune-mediated control of HBV infection characteristics. The possibility of treatment discontinuation in $\mathrm{CHB}$ patients was more likely in the Peg-IFN therapy group in our study.

We found that in the Peg-IFN group, anti-HBs titers of five patients were lasted longer than six months and one patient from the entecavir treatment group had the anti-HBs titer durability. Following the discontinued Peg-IFN therapy, SVR off-treatment in long-term treatment had a chance of HBsAg seroconversion and durable immunity when compared with NAs which also requires long-term administration (2). Actually, there is limited information regarding the level of anti-HBs titer and their duration related with the endpoint of CHB treatments and their long-term efficacy.

There are some limitations in our long-term based retrospective study: firstly, genotype D is known with the lowest rate of virologic response in Peg-IFN treatment (29). In Turkey, genotype $D$ is predominant in $\mathrm{CHB}$ patients $(30,31)$. It is worthwhile to note that the $\mathrm{CHB}$ patients distributed into the various treatment groups which displayed virologic and serological responses were infected with HBV genotypes other than genotype D. Secondly, quantitative $\mathrm{HBsAg}$ is not available in our hospital, therefore, the comparison, between the Peg-IFN and the NAs treatment groups could not be established. There may be more efficient parameters for the longterm surveillance of serological responses to the treatment.

\section{Conclusion}

In conclusion, Peg-IFN treatment was found to be highly efficient based on SVR, HBeAg and HBsAg seroconversion rates when compared with NAs treatment during long-term follow-up in Turkish CHB patients. Therefore, Peg-IFN appears to be the firstchoice treatment approach in particular patients with $\mathrm{CHB}$ until a new era in which HBV is cured.

Acknowledgments: MD. Ferdiye Taner edited the article in terms of English.

\section{Ethics}

Ethics Committee Approval: This study was approved by the Clinical Research Ethics Committee of Antalya Hospital of Health Sciences University (decision no: 7/13-04.13.2017).

Informed Consent: All patients were given informed consent. Peer-review: Externally and internally peer-reviewed.

\section{Authorship Contributions}

Concept: F.S., Design: F.S., Data Collection or Processing: F.S., Ü.U., Analysis or Interpretation: F.S., M.S., Literature Search: F.S., M.S., Writing: F.S., M.S. 
Conflict of Interest: No conflict of interest was declared by the authors.

Financial Disclosure: The authors declared that this study received no financial support.

\section{References}

1. Terrault NA, Bzowej NH, Chang KM, Hwang JP, Jonas MM, Murad MH; American Association for the Study of Liver Diseases. AASLD guidelines for treatment of chronic hepatitis B. Hepatology. 2016;63:261-283

2. European Association for the Study of the Liver. Electronic address: easloffice@easloffice.eu; European Association for the Study of the Liver. EASL 2017 Clinical Practice Guidelines on the management of hepatitis B virus infection. J Hepatol. 2017;67:370-398.

3. Sarin SK, Kumar M, Lau GK, Abbas Z, Chan HL, Chen CJ, Chen DS, Chen HL, Chen PJ, Chien RN, Dokmeci AK, Gane E, Hou JL, Jafri W, Jia J, Kim JH, Lai CL, Lee HC, Lim SG, Liu CJ, Locarnini S, A Mahtab M, Mohamed R, Omata M, Park J, Piratvisuth T, Sharma BC, Sollano J, Wang FS, Wei L, Yuen MF, Zheng SS, Kao JH. Asian-Pacific clinical practice guidelines on the management of hepatitis B: a 2015 update. Hepatol Int. 2016;10:1-98.

4. LoLok AS, McMahon BJ, Brown RS Jr, Wong JB, Ahmed AT, Farah W, Almasri J, Alahdab F, Benkhadra K, Mouchli MA, Singh S, Mohamed EA, Abu Dabrh AM, Prokop LJ, Wang Z, Murad MH5, Mohammed K. Antiviral therapy for chronic hepatitis B viral infection in adults: A systematic review and meta-analysis. Hepatology. 2016;63:284-306.

5. Lucifora J, Protzer U. Attacking hepatitis B virus cccDNA-the holygrail to hepatitis B cure. J Hepatol. 2016;64(Suppl 1):S41-S48.

6. Guidelines for the prevention, care and treatment of persons with chronic hepatitis B infection. Geneva: World Health Organization; 2015 Mar. Executive Summary. Available from: https://www.ncbi. nlm.nih.gov/books/NBK305541/

7. Terrault NA, Bzowej NH, Chang KM, Hwang JP, Jonas MM, Murad MH; American Association for the Study of Liver Diseases. AASLD guidelenes for treatment of chronic hepatitis B. Hepatology. 2016;63:261-283.

8. Brown RS Jr, McMahon BJ, Lok AS, Wong JB, Ahmed AT, Mouchli MA, Wang Z, Prokop LJ, Murad MH, Mohammed K. Antiviral therapy in chronic hepatitis B viral infection during pregnancy: A systemic review and meta-analysis. Hepatology. 2016;63:319-333.

9. Kim V, Abreu RM, Nakagawa DM, Baldassare RM, Carrilho FJ, Ono SK. Pegylated interferon alfa for chronic hepatitis B: systematic review and meta-analysis. J Viral Hepat. 2016;23:154-169.

10. Toy M, Önder FO, Wörmann T, Bozdayi AM, Schalm SW, Borsboom GJ, van Rosmalen J, Richardus JH, Yurdaydin C. Age- and regionspecific hepatitis B prevalence in Turkey estimated using generalized linear mixed models: a systematic review. BMC Infect Dis. 2011:11:337

11. Mese S, Nergiz S, Tekes S, Gul K. Seroprevalence of serum HBsAg positivity and hepatitis delta virus infection among blood donors in Southeastern Turkey. Clin Ter. 2014;165:95-98.

12. Tozun N, Ozdogan O, Cakaloglu Y, Idilman R, Karasu Z, Akarca U, Kaymakoglu S, Ergonul O. Seroprevalence of hepatitis B and $\mathrm{C}$ virus infections and risk factors in Turkey: a fieldwork TURHEP study. Clin Microbiol Infect. 2015;21:1020-1026.

13. Kemal Celen M, Tekin Koruk S, Aygen B, Dal T, Karabay O, Tosun S, Koksal I, Turgut H, Onlen Y, Balik I, Yildirim N, Sinan Dal M, Ayaz C, Tabak F. The characteristics of patients with chronic hepatitis B in Turkey. Med Glas (Zenica). 2014;11:94-98.

14. IMS Health Turkey, January 2017: www.imshealth.com/portal/site/ imshealth

15. Ishak K, Baptista A, Bianchi L, Callea F, De Groote J, Gudat F, Denk H, Desmet V, Korb G, MacSween RN, et al. Histological grading and staging of chronic hepatitis. J Hepatol. 1995;22:696-699.

16. Korkmaz P, Usluer G, Ozgunes I, Kartal ED, Erben N, Alpat SN.
Comparison of adefovir dipivoxil and pegylated interferon alpha2a treatment in chronic hepatitis B patients. North Clin Istanb. 2014;1:26-32.

17. Chon YE, Kim DJ, Kim SG, Kim IH, Bae SH, Hwang SG, Heo J, Jang JW, Lee BS, Kim HJ, Jun DW, Kim KM, Chung WJ, Choi MS, Jang JY, Yim HJ, Tak WY, Yoon KT, Park JY, Han KH, Suk KT, Lee HW, Jang BK, Ahn SH. An observational, multicenter, cohort study evaluating the antiviral efficacy and safety in korean patients with chronic hepatitis $B$ receiving pegylated interferon alpha $2 a$ (Pegasys). Medicine (Baltimore). 2016;95:e3026.

18. Yamazhan T, Kurtaran B, Pullukçu H, Yüksel E, Özkaya D, Taşbakan MI, Sipahi OR, Durusoy R, Aksu HS. Pegylated interferon in $\mathrm{HBeAg}$ positive and negative chronic hepatitis B patients: post treatment 1-year results of three Turkish center. J Chemother. 2014;26:339341.

19. Iloje UH, Yang HI, Chen CJ. Naturel history of chronic hepatitis B: what exactly has REVEAL Revealed. Liver Int. 2012;32:1333-1341.

20. Marcellin P, Gane E, Buti M, Afdhal N, Sievert W, Jacobson IM, Washington MK, Germanidis G, Flaherty JF, Aguilar Schall $R$, Bornstein JD, Kitrinos KM, Subramanian GM, McHutchison JG, Heathcote EJ. Regression of cirrhosis during treatment with tenofovir disoproxil fumarate for chronic hepatitis B: a 5-year openlabel follow-up study. Lancet. 2013;381:468-475.

21. Idilman R, Gunsar F, Koruk $M$, Keskin O, Meral CE, Gulsen $M$, Elhan AH, Akarca US, Yurdaydin C. Long-term entecavir or tenofovir disoproxil fumarete therapy in treatment-naive chronic hepatitis $B$ patients in the real-world setting. J Viral Hepat. 2015;22:504-510.

22. Yuen MF, Ann SH, Chen DS, Chen PJ, Dusheiko GM, Hou JL, Maddrey WC, Mizokami M, Seto WK, Zoulim F, Lai CL. Chronic hepatitis B virus infection: disease revisit and management recommendations. J Clin Gastroenterol. 2016;50:286-294.

23. Guyatt $G H$, Oxman $A D$, Vist GE, Kunz R, Falck-Ytter $Y$, AlonsoCoello P, Schünemann HJ; GRADE Working Group. GRADE: An emerging concensus on rating quality of evidence and strength os recommendations. BMJ. 2008;336:924-692.

24. Nagata N, Kagawa T, Hirose S, Arase Y, Tsuruya K, Anzai K, Shiraishi $K$, Mine T. Off-treatment durability of antiviral response to nucleosid analouges in patients with chronic hepatitis B. BMC Gastroenterol. $2016 ; 16: 38$

25. Xing $\mathrm{T}, \mathrm{Xu} \mathrm{H}, \mathrm{Cao} L, \mathrm{Ye} M$. HBeAg seroconversion in HBeAg-positive chronic hepatitis B patients receiving long-term nucleos(t)ide analog treatment: A systematic review and network meta-analysis. PLoS ONE. 2017;12:e0169444.

26. Marcellin $P$, Xie $Q$, Paik SW, Flisiak R, Piratvisuth $T$, Petersen J, Asselah T, Cornberg M, Ouzan D, Foster GR, Papatheodoridis GV, Messinger D, Regep L, Bakalos G, Alshuth U, Wedemeyer H. Effectiveness of peginterferon alfa-2a therapy in $\mathrm{HBeAg}$-positive and $\mathrm{HBeAg}$-negative patients with chronic hepatitis $\mathrm{B}$ : final results 3 years post-treatment of the prospective, global, observational S-collate study. J Hepatol 2016;64:598-599.

27. Ahn J, Lee HM, Lim JK, Pan CQ, Nguyen MH, Ray Kim W, Mannalithara A, Trinh H, Chu D, Tran T, Min A, Do S, Te H, Reddy $\mathrm{KR}$, Lok AS. Entecavir safety and effectiveness in a national cohort of treatment-naive chronic hepatitis B patients in the US-the ENUMERATE study. Aliment Pharmacol Ther. 2016;43:134-144.

28. Petersen J, Heyne R, Mauss S, Schlaak J, Schiffelholz W, Eisenbach C, Hartmann H, Wiese M, Boeker K, Loehr HF, John C, Leuschner M, Trautwein C, Felten G, Trein A, Krause W, Ruppert S, Warger T, Hueppe D. Effectiveness and safety of tenofovir disoproxil fumarate in chronic hepatitis B: A3-year prospective field practice study in Germany. Dig Dis Sci. 2016;61:3061-3071.

29. Chu CM, Liaw YF. Hepatitis B surface antigen seroclearance during chronic HBV infection. Antivir Ther. 2010;15:133-143.

30. Sayan M, Akhan SC, Meric M. Naturally occurring amino-acid substitutions to nucleos(t)ide analogues in treatment naive Turkish patients with chronic hepatitis B. J Viral Hepat. 2010;17:23-27.

31. Sayan M. Dogan C. Genotype/subgenotype distribition of hepatitis B virus among hemodialysis patients with Chronical Hepatitis B. Ann Hepatol. 2012:11:849-854 